Article

\title{
Effect of Synthesis Conditions on the Controlled Growth of MgAl-LDH Corrosion Resistance Film: Structure and Corrosion Resistance Properties
}

\author{
Muhammad Ahsan Iqbal *(D) and Michele Fedel * \\ Department of Industrial Engineering, University of Trento, via Sommarive 9, 38123 Trento, Italy \\ * Correspondence: muhammadahsan.iqbal@unitn.it (M.A.I.); michele.fedel@unitn.it (M.F.); \\ Tel.: +39-320-022-7519 (M.A.I.); +39-461-285-354 (M.F.)
}

Received: 10 December 2018; Accepted: 2 January 2019; Published: 7 January 2019

check for updates

\begin{abstract}
In this study, a series of MgAl-layered double hydroxide (LDH) thin films were synthesized by a single step hydrothermal process at different synthetic conditions on AA6082, and the combined effect of reaction temperatures and crystallization times on in situ growth MgAl-LDH structural geometry, growth rate, and more importantly on the corresponding corrosive resistance properties are briefly discussed. The synthesis of LDH was performed at reaction temperatures of 40, 60, 80, and $100^{\circ} \mathrm{C}$, while the treatment time was varied at 12,18 , and $24 \mathrm{~h}$. The as-prepared synthetic coatings were characterized by scanning electron microscopy (SEM), energy dispersion spectroscopy (EDS), X-ray diffraction (XRD) and Fourier transform infrared spectroscopy (FT-IR), while the corresponding corrosion protection efficiency of the developed coating was studied through potentiodynamic polarization studies and electrochemical impedance spectra. The findings demonstrated that extended crystallization time and reaction temperature impart a significant effect on the oriented growth of layered double hydroxide, the surface morphology, and on the film thickness, which had a remarkable influence on the LDH corrosion resistance ability. The LDH coated specimen developed at $100{ }^{\circ} \mathrm{C}$ for $18 \mathrm{~h}$ reaction time showed a more compact and dense structure compared to the traditional platelet structure obtained at $80^{\circ} \mathrm{C}$ for $24 \mathrm{~h}$ crystallization time, and interestingly that compact structure exhibited the lowest corrosion current density, up to five orders of magnitude lower than that of bare AA6082.
\end{abstract}

Keywords: MgAl-layered double hydroxide; EIS; XRD; FT-IR; AA6082; corrosion protection

\section{Introduction}

Aluminum and its alloys are considered promising materials for a number of applications due to their high strength to weight ratio and relatively high thermal and electrical conductivities, along with their abundance and low price. In addition, aluminum forms a passive oxide layer on its surface, which increases its corrosion resistance. On exposure to an acidic or alkaline medium, especially chloride-incorporating media, the protective oxide layer is damaged and aluminum becomes susceptive to corrosion. Various series of aluminum alloys have been developed to improve the properties of aluminum with respect to their usage applications. AA6xxx is relatively a new class of aluminum alloys which contain mainly additions of manganese, magnesium, silicon, and a small amount of copper [1-4]. Although these alloys show relatively high general corrosion resistance, they are susceptible to forms of localized corrosion, especially pitting and intergranular corrosion $[5,6]$. Therefore it has become indispensable to develop an efficient, environmentally friendly protective coating on aluminum and its alloys.

Chromate-containing conversion coatings were employed for a long time to protect aluminum alloys but since those coatings contain hexavalent chromate compounds, which have been proved 
toxic for the environment and hazardous to health $[7,8]$, efforts have been made to develop suitable alternatives. A number of approaches have been reported, including conversion coatings $[9,10]$, magnetron sputtering [11,12] anodizing [13,14], sol-gel synthesis [15,16], and self-assembly [17,18], and polymer coatings $[19,20]$ to develop non-chromate based corrosion resistance coatings. Layered double hydroxide, a promising type of chemical conversion coatings and also known as hydrotalcite-like compounds or anionic clays, have had prominent attention in the fields of biomedical science, applied chemistry, and environmental purifications and recently as corrosion resistant coatings for metals [21,22]. Generally, two different methods have been employed to fabricate layered double hydroxide, the single step in situ approach $[23,24]$ and the other a colloidal assembly technique $[25,26]$. Coatings fabricated using the two-step method improved the corrosion resistance of their substrates; however, the poor adhesion of the film to the substrate was reported and also the fabrication process itself appears slightly complicated [27]. Numerous works have been reported to fabricate different types of layered double hydroxide to protect the light metals alloys [27-30]. The growth rate of crystals and their size and distribution can be controlled by adjusting the crystallization time and the reaction temperature. The properties and structural characteristics of MgAl-layered double hydroxide (LDH) actively depend upon the fabrication method, operating parameters, and conditions used for the fabrication [31-34]. Therefore, the optimization of the synthesis parameters plays an important role in developing a suitable structure for numerous applications. In our previous work, we reported the effect of different salt concentrations on LDH structural growth to obtain various distinct LDH morphologies as well as their effect on corrosion resistance properties [35]. However, the combined effect of extended reaction temperature and the aging time on in situ growth $\mathrm{MgAl}-\mathrm{LDH}$ structural growth rate without using any complexation agents (used to promote specific LDH structural growth) to further their impact on their corresponding corrosive resistance behavior has not yet been thoroughly investigated. In this work we succeeded to synthesize a series of $\mathrm{MgAl}-\mathrm{NO}_{3} \mathrm{LDH}$ film on the surface of AA6082 by using magnesium salt only, and developed a range of balanced combinations of reaction temperature and aging time, at constant initial cationic concentration $\left(\mathrm{Mg}^{2+}\right)$ to investigate in detail the impact of the above-mentioned parameters on LDH geometry, structural growth, morphology, and their effect on the corresponding corrosion resistance properties. In particular, in this study, the one-step in situ growth method was used to develop MgAl-LDH coatings on AA6082 at different combinations of extended reaction temperature and crystallization time without using any surfactants or complexation reagents. This was done in order to understand the effect of the mentioned parameters on the geometry of LDH crystallites, film growth, and on the deposition rate to explain the relationship of LDH structural variations with its anticorrosion behavior. This work provides insight into the corrosion resistance properties of $\mathrm{MgAl}-\mathrm{LDH}$, and into the correlation between the electrochemical response of the coatings and their structural properties.

\section{Experimental}

\subsection{Materials}

The AA6082 extruded bar was purchased from Metal Center (Trento, Italy), which mainly consists of $(0.60 \%-1.20 \%)$ magnesium, ( 0.50$)$ iron, $(0.70 \%-1.30 \%)$ silicon, $(0.10 \%)$ copper, $(0.40 \%-1.00 \%)$ manganese and of a balance percentage of aluminum. The $\mathrm{Mg}\left(\mathrm{NO}_{3}\right)_{2} \cdot 6 \mathrm{H}_{2} \mathrm{O}$, (purity $98 \%$ ), $\mathrm{NH}_{4} \mathrm{NO}_{3}$ (purity 95\%)and $\mathrm{NaOH}$ (purity $\geq 98 \%$ ) were purchased from Sigma-Aldrich Corporation (Saint Louis, MO, USA).

\subsection{Synthesis of $M g-A l$ Layered Double Hydroxide Film}

The AA608 specimens were initially ground with silicon carbon paper, starting from 500 grit paper to 1000, 2400, and 4000-grit respectively. The samples were cleaned with deionized water and further ultrasonically in pure ethanol for $15 \mathrm{~min}$. Lastly, the specimens were immersed in a $0.1 \mathrm{M}$ aqueous $\mathrm{NaOH}$ solution for one minute to etch the oxide layer on the surface of the alloy. 
A $0.05 \mathrm{M}\left(\mathrm{Mg}\left(\mathrm{NO}_{3}\right)_{2} \cdot 6 \mathrm{H}_{2} \mathrm{O}\right)$ solution was prepared in $1000 \mathrm{~mL}$ deionized water and the $\mathrm{pH}$ of the solution was adjusted to 10.0 by the dropwise addition of ammonium hydroxide solution. The solution was poured into a four bottleneck heating flask (Sigma-Aldrich Glassware) and pretreated aluminum samples $\left(3.14 \mathrm{~cm}^{2}\right)$ were immersed vertically in the solution. The experiments were performed at 40,60 , 80 , and $100{ }^{\circ} \mathrm{C}$ reaction temperature, for 12,18 , and $24 \mathrm{~h}$, under nitrogen bubbling. The samples were washed with deionized water after the experiments completion and were dried at room temperature. Figure 1 represents the general schematic diagram of the layered double hydroxide.

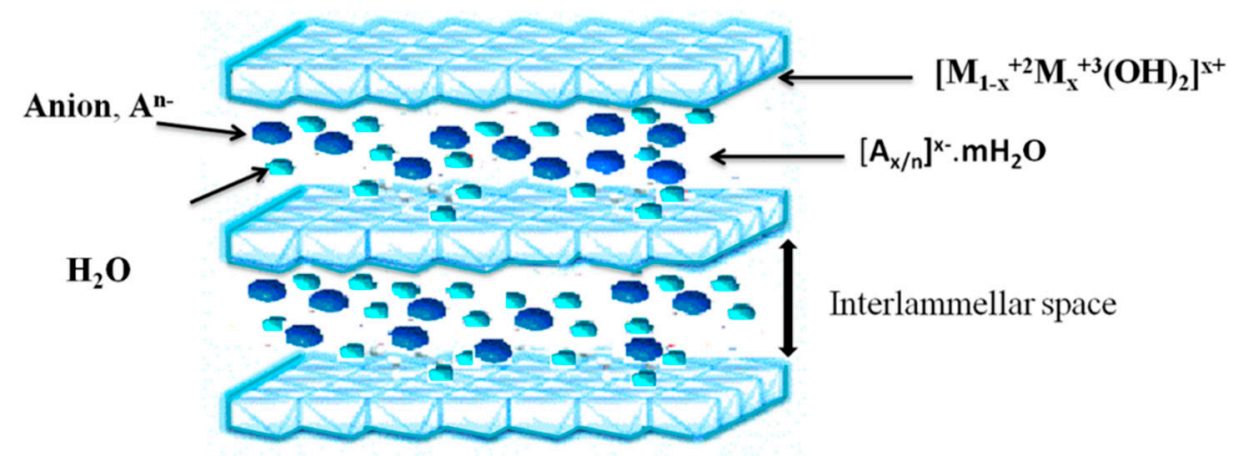

Figure 1. Schematic illustration of layered double hydroxides.

\section{Characterization}

A scanning electron microscopy (JEOL-IT300 microscope equipped with an EDS detector, JEOL Ltd, Tokyo, Japan) was used to analyze the morphology and the microstructural features of MgAl-LDH, while the elemental analysis of the thin film was studied through energy dispersive electron microscopy (SEM-EDX) in planner mode. XRD patterns of the calcined and uncalcined LDH coated samples were recorded by X-ray diffraction (XRD) (X'Pert High Score diffractometer, Rigaku, Tokyo, Japan) at ambient conditions by using cobalt $K \alpha(\lambda=1.789 \AA)$ emission source at $10 \mathrm{~mA}$ and $30 \mathrm{kV}$ conditions. The step size of $0.005^{\circ}$ was adjusted in the $2 \theta$ range of $5^{\circ}-110^{\circ}$. The peak reflections at the (003) planes of layered double hydroxide were studied to measure the basal spacing and to define the full-width half maximum (FWHM) for the measurement of crystallite size (D), by using the Scherrer formula. The lattice parameters of $\mathrm{Mg}-\mathrm{Al}$ layer double hydroxide were calculated by using Equation (1) [34], where $d$ is the lattice spacing calculated by Braggs law.

$$
\frac{1}{d^{2}}=\frac{4}{3}\left(h^{2}+h k+\frac{k^{2}}{a^{2}}\right)+\frac{l^{2}}{c^{2}}
$$

Fourier transformed infrared spectra (FTIR), Varian 4100 FTIR Excalibur Series instrument (Varian, Santa Clara, CA, USA), in the attenuated total reflectance (ATR) mode were recorded to analyze surface functional groups and the chemical bonding of the samples, in the range of $550-4000 \mathrm{~cm}^{-1}$ with a $4 \mathrm{~cm}^{-1}$ resolution and at 32 scans, by using a diamond crystal as Internal Reflective element (IRE). The electrochemical measurements were conducted (PAR Parstat 2273, Ametek, Berwyn, PA, USA) $0.1 \mathrm{M} \mathrm{NaCl}$ solution to understand the anti-corrosion properties performed at ambient conditions under Faraday cage to minimize the external noise on the system. A relatively diluted electrolyte $(0.1 \mathrm{M})$ was employed in order to better highlight the differences between the investigated samples. A traditional three electrode setup was used, where the platinum mesh was used as a counter electrode while $\mathrm{MgAl}-\mathrm{LDH}$ and $\mathrm{Ag} / \mathrm{AgCl} / \mathrm{KCl}(+210 \mathrm{mV}$ vs. Standard Hydrogen Electrode (SHE)) were used as working and reference electrode respectively. The MgAl-LDH was exposed to the electrochemical solution for $30 \mathrm{~min}$ in $0.1 \mathrm{M} \mathrm{NaCl}$ solution before the measurement, for the system stabilization. The polarization curves were obtained with a sweep rate of $2 \mathrm{mV} / \mathrm{s}$. The impedance measurements (EIS) were performed at the open circuit potential (OCP) over frequencies ranging from $100 \mathrm{kHz}$ down to $10 \mathrm{mHz}$ at a $5 \mathrm{mV}$ (rms) amplitude. 


\section{Results and Discussion}

\subsection{XRD Analysis}

Figure 2a,b shows the XRD pattern of MgAl-LDH thin film developed on the AA6082 at various temperature and crystallization time periods. The XRD pattern of the MgAl layer double hydroxide at $40{ }^{\circ} \mathrm{C}-24 \mathrm{~h}$ and at $60,80,100{ }^{\circ} \mathrm{C}$ for 12,18 , and $24 \mathrm{~h}$ crystallization time, demonstrated the characteristic peaks of layered double hydroxide structure, described in the literature [35], further the sharpness of the peaks suggested an ordered structure of LDH layers. It can be seen that synthesis temperature and crystallization time have an influential effect on characteristic peaks. The (003), (006), (009), (110), and (113) characteristics peaks of crystal planes are related to the $\mathrm{MgAl}-\mathrm{NO}_{3} \mathrm{LDH}$ film. The intensity and broadness of the reflection peaks vary with the increase of temperature and $t$ also depend upon crystallization aging time. When the samples were synthesized at $60^{\circ} \mathrm{C}$ and lower aging time $(12$ and $18 \mathrm{~h}$ ), the pattern exhibited low intensity and a broader peak which describe their low crystallinity. At higher temperature range, for instance, 80 and $100{ }^{\circ} \mathrm{C}$, the reflection peaks exhibited sharp and high intense narrow peaks which describe well the crystalline and ordered structure. The intense reflection peaks of (003) at low $2 \theta$ value exhibited an interlayer distance of $\approx 0.80 \mathrm{~nm}$ and the reflection peak could further be used to calculate the cell parameter " $c$ " by the correlation " $c=3 d_{003}$ ", while the $d_{110}$ interlayer thickness was used to calculate the cell parameter " $a$ " by the correlation " $a=2 d_{110}$ ". The basal spacing of MgAl LDH slightly shifted to lower angle with the effect of enhanced temperature and crystallization aging time, indicating the strong intercalation of $\mathrm{NO}_{3}{ }^{-}$ions. However due to the formation of carbonate anions, small absorption peaks of $d_{003}$ at $40{ }^{\circ} \mathrm{C}-24 \mathrm{~h}, 60{ }^{\circ} \mathrm{C}-18 \mathrm{~h}$ were also observed. Fourier transform-infrared spectroscopy (FT-IR) spectra further confirmed the presence of $\mathrm{CO}_{3}{ }^{2-}$ nions. The interlayer thickness, lattice constants of " $a$ " and " $c$ ", and crystallite size for $\mathrm{Mg}-\mathrm{Al}$ LDHs thin film on AA6082 are listed in Table 1.
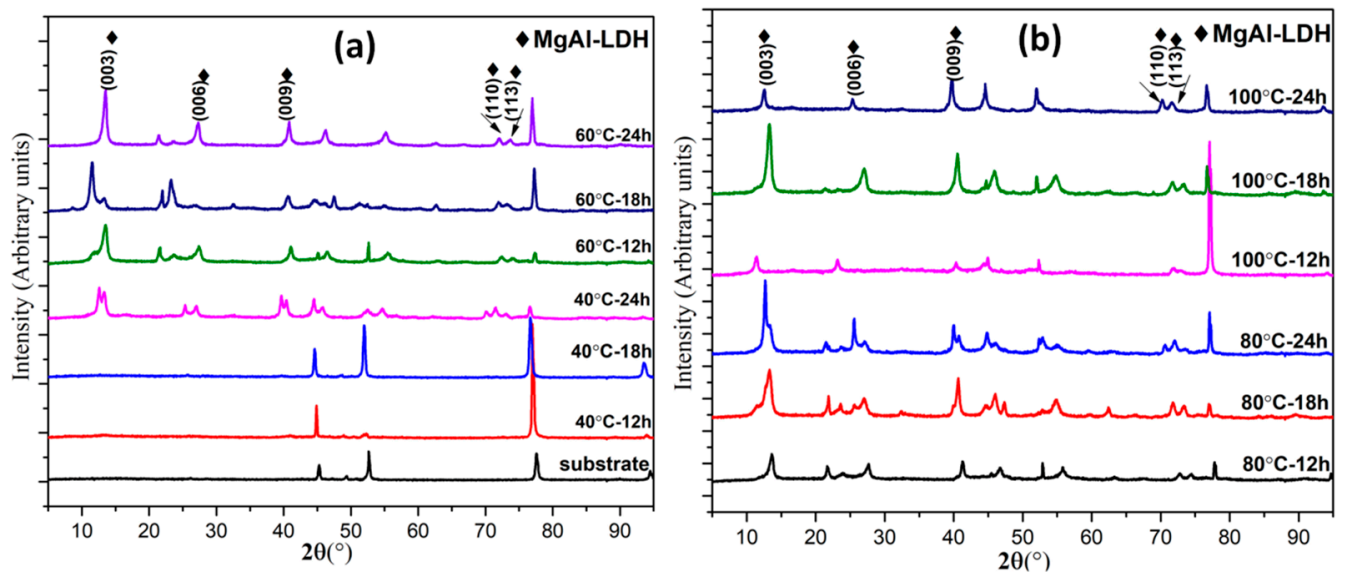

Figure 2. The XRD spectra of Mg-Al layered double hydroxide (LDH) film samples developed on aluminum alloy AA6082 obtained at various reaction temperature and crystallization times.

\subsection{Fourier Transform Infrared Spectroscopy (FTIR)}

The selective samples, synthesized at various temperatures and crystallization times, were further investigated by FTIR analysis. FTIR spectra in attenuated total reflection mode were recorded, as shown in Figure 3. All the samples showed almost similar types of features. The broadbands displayed in the range of 3370-3427 $\mathrm{cm}^{-1}$ were assigned to $\mathrm{OH}$ group stretching and the absorption band around, $1627-1633 \mathrm{~cm}^{-1}$ was caused due to the flexural oscillation peaks of interlayer water molecules [36]. Moreover, the absorption peaks around $1350 \mathrm{~cm}^{-1}$ were assigned to the asymmetric stretching bond of intercalated $\mathrm{NO}_{3}{ }^{-}$[37]. The small peak around $1520 \mathrm{~cm}^{-1}$ corresponded to the $\mathrm{CO}_{3}{ }^{2-}$ ions, which shows the presence of a small number of carbonate ions in the LDH phase. The bond at 655,751 , and 
$1202 \mathrm{~cm}^{-1}$ may be associated with Al-OH stretching [38]. The absorption peaks around $550-770 \mathrm{~cm}^{-1}$ correspond to the lattice vibration of metal-oxygen bonds (M-O) [39].

Table 1. Cell parameters and sizes of the coherent domains determined for the $\mathrm{Mg}-\mathrm{Al}$ layered double hydroxide $(\mathrm{LDH})$ precursor powders from $\mathrm{X}$-ray diffraction.

\begin{tabular}{cccccc}
\hline Sample & $\begin{array}{c}\text { Cell Parameter, } \\
\boldsymbol{a}(\mathbf{n m})\end{array}$ & $\begin{array}{c}\text { Cell Parameter, } \\
\boldsymbol{c}(\mathbf{n m})\end{array}$ & $\begin{array}{c}\text { Interlayer } \\
\text { Distance, } \boldsymbol{d}_{\mathbf{0 0 3}} \\
(\mathbf{n m})\end{array}$ & $\begin{array}{c}\text { Interlayer } \\
\text { Distance, } \boldsymbol{d}_{\mathbf{1 1 0}} \\
\mathbf{( n m )}\end{array}$ & $\begin{array}{c}\text { Crystallite } \\
\text { Size, } \boldsymbol{D}(\mathbf{n m})\end{array}$ \\
\hline $40^{\circ} \mathrm{C}-24 \mathrm{~h}$ & 0.308 & 2.329 & 0.776 & 0.154 & 11.214 \\
$60^{\circ} \mathrm{C}-12 \mathrm{~h}$ & 0.306 & 2.296 & 0.765 & 0.153 & 12.908 \\
$60^{\circ} \mathrm{C}-18 \mathrm{~h}$ & 0.305 & 2.668 & 0.889 & 0.152 & 7.608 \\
$60^{\circ} \mathrm{C}-24 \mathrm{~h}$ & 0.305 & 2.294 & 0.765 & 0.152 & 11.657 \\
$80^{\circ} \mathrm{C}-12 \mathrm{~h}$ & 0.303 & 2.275 & 0.759 & 0.151 & 6.685 \\
$80^{\circ} \mathrm{C}-18 \mathrm{~h}$ & 0.306 & 2.461 & 0.820 & 0.153 & 6.987 \\
$80^{\circ} \mathrm{C}-24 \mathrm{~h}$ & 0.311 & 2.412 & 0.804 & 0.155 & 8.465 \\
$100^{\circ} \mathrm{C}-12 \mathrm{~h}$ & 0.311 & 2.691 & 0.897 & 0.155 & 5.929 \\
$100^{\circ} \mathrm{C}-18 \mathrm{~h}$ & 0.311 & 2.391 & 0.797 & 0.156 & 6.165 \\
$100^{\circ} \mathrm{C}-24 \mathrm{~h}$ & 0.311 & 2.463 & 0.821 & 0.157 & 6.411 \\
\hline
\end{tabular}

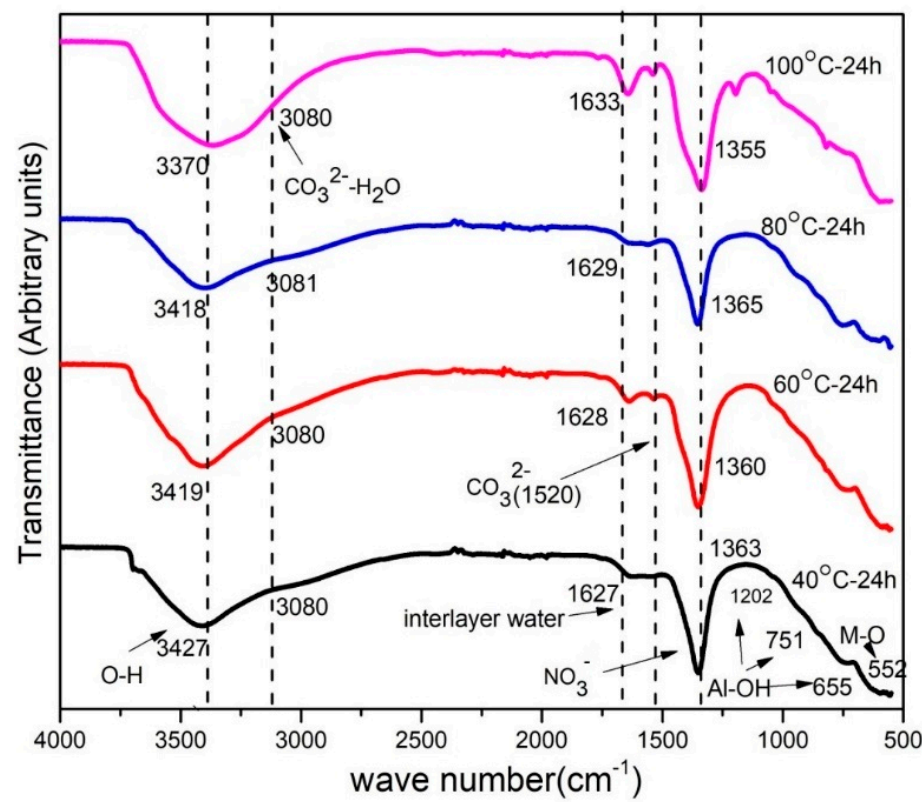

Figure 3. ATR-FTIR spectra of Mg-Al LDH powder, scraped from as-prepared MgAl-LDH coated samples fabricated at different reaction temperatures.

\subsection{Scanning Electron Microscopy (SEM)}

As revealed from the SEM observations, shown in Figure 4, a compact and uniform interviewed LDH structure was obtained by the increase of reaction temperature and of aging time, moreover distinct surface morphological variations were also observed. Initially, the LDH granules started to originate and developed into distinct platelet structure with increase of reaction temperature and crystallization time, while on further increase of the temperature and aging time, the nano-sheets of the $\mathrm{LDH}$ structure fused to form a compact blade like LDH structure. For example at $80^{\circ} \mathrm{C}$ temperature and $24 \mathrm{~h}$ aging time, a fully groomed curved shaped platelet morphology was obtained which fused on further increase in temperature and appeared as a compact needle-shaped structure. The atomic composition of LDH, calculated by energy disperse spectroscopy (EDS) plane scanning, is listed in Table 2. The EDS findings showed that the coated structure is mainly composed of $\mathrm{Mg}, \mathrm{Al}, \mathrm{N}$, and oxygen. A small amount of carbon is also evident in the EDS study, caused by contamination from 
air, which results in the formation of carbonate anions. The atomic ratio of $\mathrm{Mg} / \mathrm{Al}$ varies with the effect of temperature and crystallization time. Table 2 showed that with a higher reaction temperature and crystallization time, a higher ratio of $\mathrm{Mg} / \mathrm{Al}$ is obtained. The oxygen content also varied with the influence of temperature and time. The atomic ratio of $\mathrm{Mg}: \mathrm{Al}$ lies in the range of 2.5:1-3.87:1, which provides a rough approximation of the $\mathrm{MgAl} \mathrm{LDH}$ assembly. Note that the $\mathrm{Mg}: \mathrm{Al}$ ratio increases with the duration of the treatment regardless of the temperature. The duration of the treatment seems therefore to affect the chemical composition of the LDHs which enrich with Mg during the long immersion time. The possible formation of MgAl LDH on the AA6082 surface may start with the dissolution of aluminum in the basic solution to release $\mathrm{Al}^{3+}$ ions (aluminum surface is partially dissolved on contact with the high $\mathrm{pH}$ solution and generated aluminum oxides) [40], which react with the water to form $\mathrm{Al}(\mathrm{OH})_{3}$ while the final step is related to the precipitation of $\mathrm{Mg}^{2+}$ and $\mathrm{OH}^{-}$on the surface of the $\mathrm{Al}(\mathrm{OH})_{3}$ surface to form the pre-MgAl LDH hydroxide mixture. The ammonium nitrate continuously hydrolyzed to form $\mathrm{NO}_{3}{ }^{-}$in the system, along with the release of ammonium ions which led to progressively keep the $\mathrm{pH}$ in the range of 10 . Finally, the divalent $\mathrm{Mg}^{2+}$ ions in $\mathrm{Mg}(\mathrm{OH})_{2}$ were substituted by the trivalent $\mathrm{Al}^{3+}$ ions, which result in the coexistence of $\mathrm{Al}(\mathrm{OH})_{3}$ and $\mathrm{Mg}(\mathrm{OH})_{2}$ to form a stable hydrotalcite-like LDH structure. On the other hand, the hydroxyl ions present inside the galleries were exchanged by $\mathrm{NO}_{3}{ }^{-}$ions present in the solution and as the average atomic ratio of $\mathrm{Mg}$ to $\mathrm{Al}$ is approximately around three, as shown in Table 2 (EDS analysis), it can be concluded that the final film of $\mathrm{Mg}_{3} \mathrm{Al}(\mathrm{OH})_{2} \cdot x \mathrm{NO}_{3} \cdot y \mathrm{H}_{2} \mathrm{O}$ was formed on the substrate of AA6082 and formed stacking of LDH layers one above another to form the LBL configuration (Figure 1). The obtained EDS findings are in agreement with the XRD results.

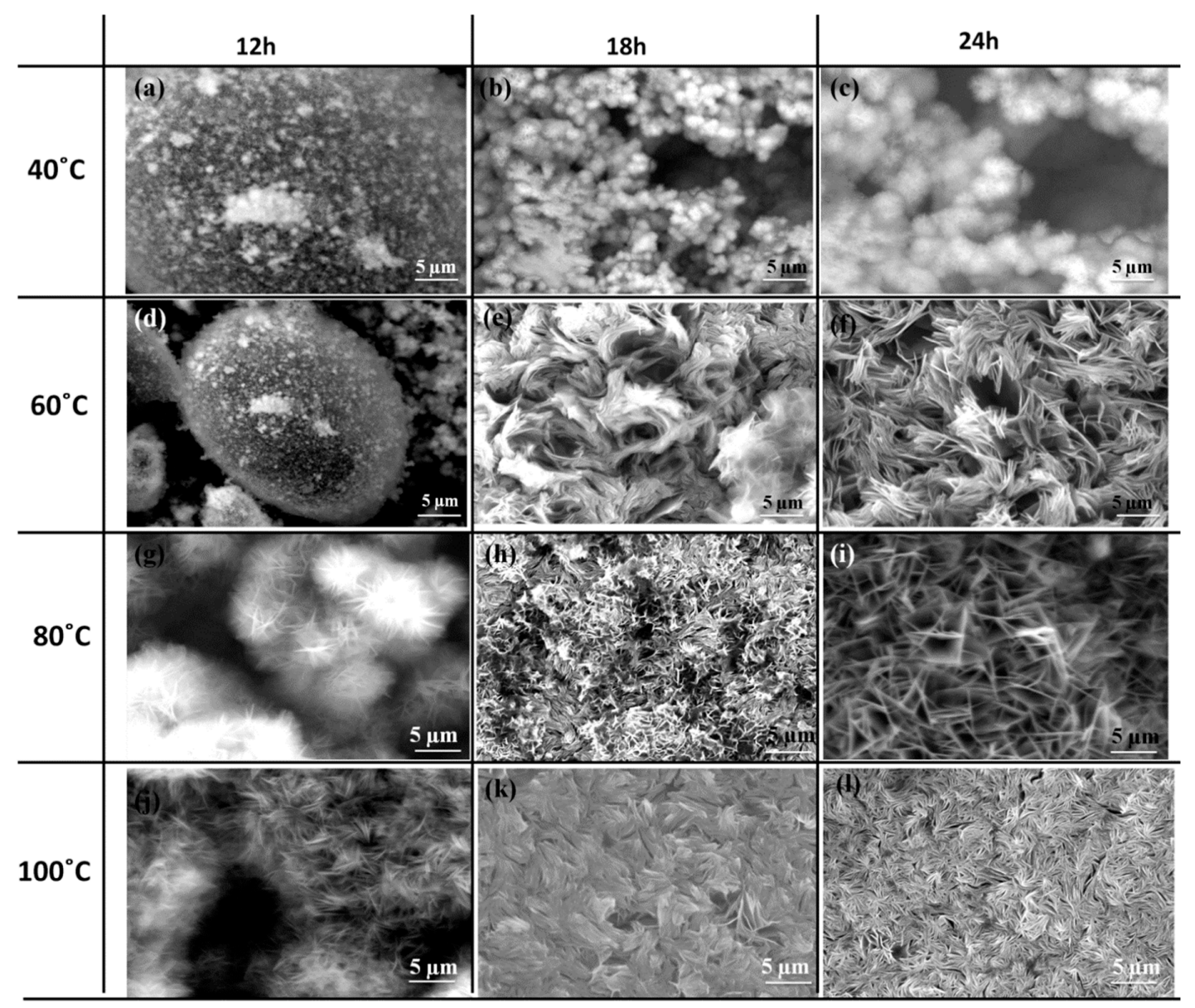

Figure 4. SEM images of LDH films developed at various reaction temperatures and crystallization times. 
Table 2. EDS study of atomic percentage at various reaction temperature and crystallization times.

\begin{tabular}{cccccc}
\hline Sample & Mg (at.\%) & Al (at.\%) & N (at.\%) & O (at.\%) & Mg/Al \\
\hline $40{ }^{\circ} \mathrm{C}-24 \mathrm{~h}$ & 17.6 & 6.8 & 3.1 & 64.7 & 2.6 \\
$60^{\circ} \mathrm{C}-12 \mathrm{~h}$ & 18.1 & 7.2 & 3.0 & 60.7 & 2.5 \\
$60^{\circ} \mathrm{C}-18 \mathrm{~h}$ & 26.2 & 7.5 & 3.3 & 57.4 & 3.5 \\
$60^{\circ} \mathrm{C}-24 \mathrm{~h}$ & 27.5 & 7.5 & 4.2 & 57.0 & 3.7 \\
$80^{\circ} \mathrm{C}-12 \mathrm{~h}$ & 19.3 & 7.3 & 3.1 & 58.7 & 2.6 \\
$80^{\circ} \mathrm{C}-18 \mathrm{~h}$ & 27.2 & 7.6 & 4.1 & 53.8 & 3.6 \\
$80^{\circ} \mathrm{C}-24 \mathrm{~h}$ & 24.7 & 6.6 & 4.7 & 56.2 & 3.8 \\
$100^{\circ} \mathrm{C}-12 \mathrm{~h}$ & 24.5 & 7.6 & 4.2 & 53.9 & 3.2 \\
$100^{\circ} \mathrm{C}-18 \mathrm{~h}$ & 28.6 & 7.5 & 4.7 & 53.9 & 3.8 \\
$100^{\circ} \mathrm{C}-24 \mathrm{~h}$ & 28.7 & 7.4 & 4.3 & 63.1 & 3.9 \\
\hline
\end{tabular}

The results from SEM (Figure 4) suggest that the synthesis conditions promote the formation of uniform and quite ordered structures. As far as the appearance of the coatings is concerned, it seems that on increasing the treatment temperature from 60 to $100{ }^{\circ} \mathrm{C}$, the LDHs layer becomes more and more compact and homogenous. Also the duration of the treatment plays a similar role: prolonged immersion in the solution promotes the formation of homogeneous LDHs structures in which the platelets are closely packed.

The effect on the film thickness of the synthesis parameters is reported in Figure 5, which shows also the cross-sectional image of $\mathrm{MgAl} \mathrm{LDH}$ at $80^{\circ} \mathrm{C}$ and $18 \mathrm{~h}$ (reported as an example). The results of the film thickness indicated that with the increase of reaction temperature and treatment time, the film thickness of coating increased. The film thickness increased from about 20.8-73.5 $\mu \mathrm{m}$ with the increase of the processing parameters. The high temperature and aging time in this study were shown to promote the growth rate of LDH formation, confirmed also by XRD and SEM analysis. It was observed that a rapid increase in film thickness was found for $100^{\circ} \mathrm{C}$ temperature and $24 \mathrm{~h}$ treatment time. However, with the increase of thickness, the interface of substrate and coating become blurred and also caused an increase in defect density, which promoted loose interaction with the substrate. In fact, some pores were observed at the interface of coating and substrate with the increase of coating thickness. This fact is expected to negatively influence the corrosion protection ability of LDH.

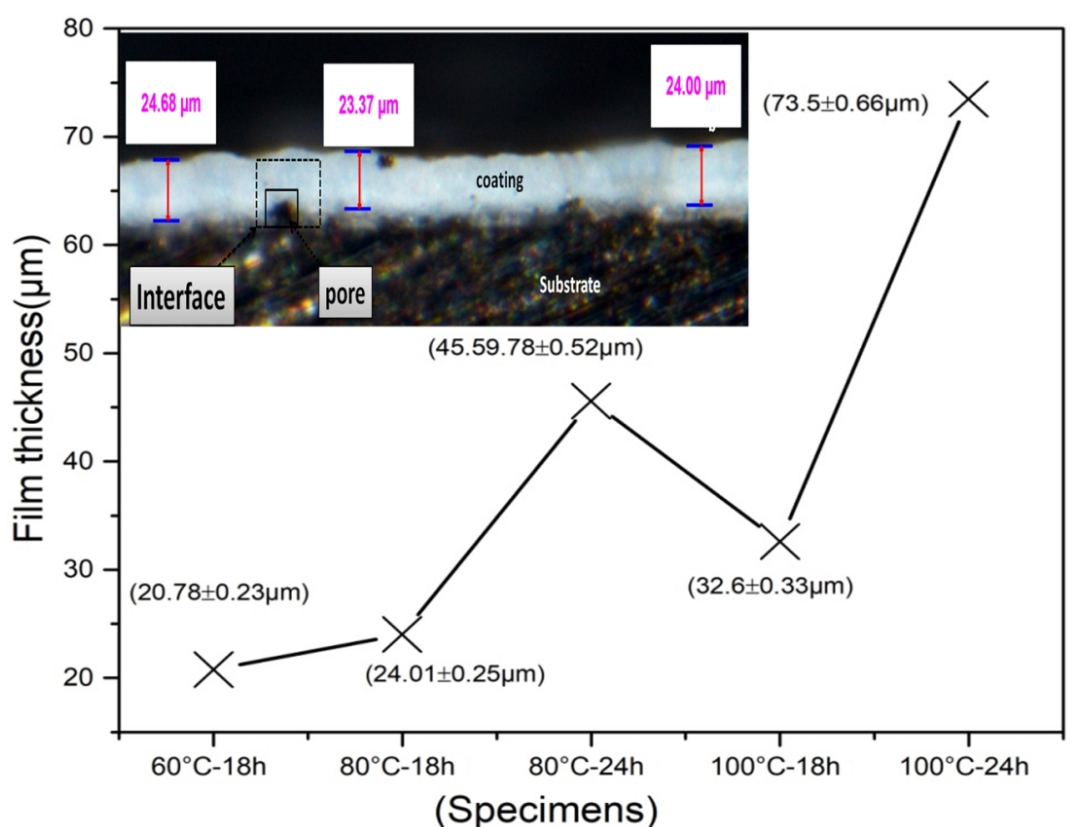

Figure 5. $\mathrm{MgAl} \mathrm{LDH}$ thickness of the film coated AA6082 estimated from the cross-sectional optical microscopic images as a function of reaction temperature and treatment time, (for representation, insight is the optical images of $\mathrm{LDH}$ at $80^{\circ} \mathrm{C}$ and $18 \mathrm{~h}$ reaction conditions.). 


\subsection{Electrochemical Study}

The as-prepared $\mathrm{MgAl}-\mathrm{LDH}$ anticorrosion behavior was investigated through electrochemical studies. Figure 6 exhibits the potentiodynamic polarization curves of all the tested samples, while the corrosion current density and corrosion potential are listed in Table 3. With the increase of synthetic reaction temperature and crystallization time, the corrosion current density decreases, and also a significant increase in the film is observed. The reduction of both the anodic and cathodic currents suggests an increase in corrosion resistance. The polarization curves of $\mathrm{MgAl} \mathrm{LDH}$ coating obtained from the specimens developed at $60^{\circ} \mathrm{C}-24 \mathrm{~h}, 80^{\circ} \mathrm{C}-18 \mathrm{~h}, 80^{\circ} \mathrm{C}-24 \mathrm{~h}, 100{ }^{\circ} \mathrm{C}-18 \mathrm{~h}$ and $100{ }^{\circ} \mathrm{C}-24 \mathrm{~h}$ showed a noticeable decrease in corrosion of both anodic and cathodic current density compared to the bare AA6082. The significant reduction of the current densities suggests that the MgAl LDH thin films can help to decrease the corrosion rate of the substrate. All the developed films on AA6082 showed lower corrosion current density along with a shift of the corrosion potential to higher values compared to bare AA6082. As one can see, for almost all the investigated samples a rise in the corrosion potential was observed as the crystallization time increased. The MgAl LDH is believed to provide corrosion protection due to the following two mechanisms: (1) the barrier effect, as they are dielectric materials which protect the metal surface by avoiding interaction with the metal substrate; (2) by entrapping $\mathrm{Cl}^{-}$ions and releasing nitrates [41]. In the case of the polarization curves, it is likely that the main protection mechanism observed is the physical barrier effect provided by the LDH layer which promotes a decrease in the flow of current.
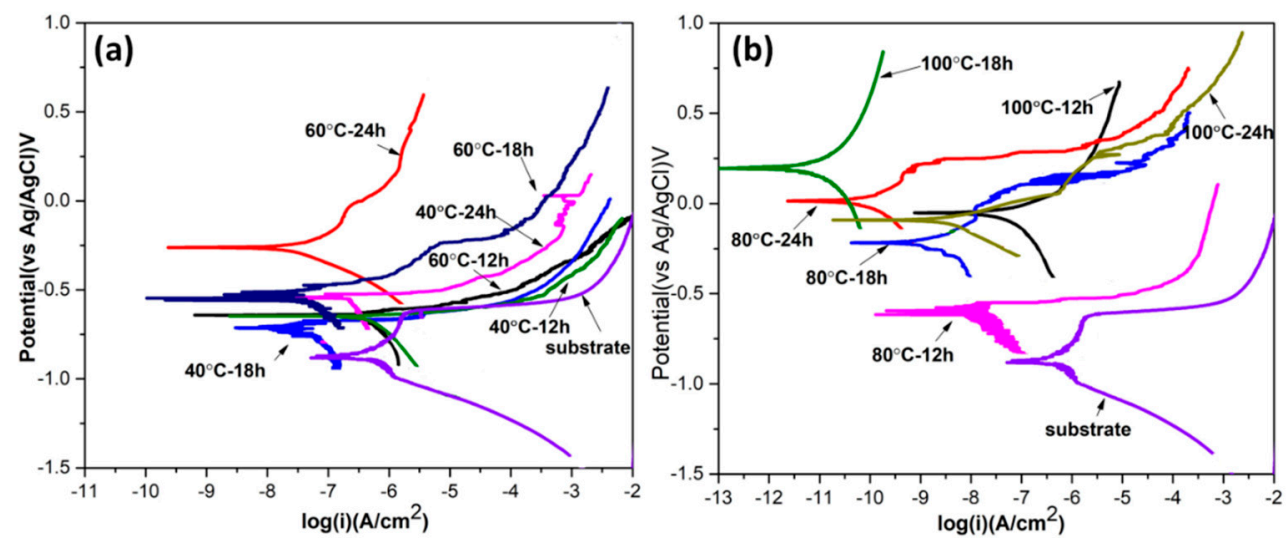

Figure 6. Polarization curves of bare AA6082 and the coated AA6082 in $0.1 \mathrm{M} \mathrm{NaCl}$ aqueous solution.

Table 3. The electrochemical parameters estimated from the polarization data in Figure 6.

\begin{tabular}{ccc}
\hline Specimens & $\boldsymbol{E}(\mathbf{v s .} \mathbf{A g} / \mathbf{A g C l})(\mathrm{V})$ & $\boldsymbol{I}\left(\boldsymbol{\mu} \mathbf{A} / \mathbf{c m}^{2}\right)$ \\
\hline $\mathrm{AA} 6082$ & -0.879 & 0.46556 \\
$40^{\circ} \mathrm{C}-12 \mathrm{~h}$ & -0.679 & 0.33138 \\
$40^{\circ} \mathrm{C}-18 \mathrm{~h}$ & -0.721 & 0.07629 \\
$40^{\circ} \mathrm{C}-24 \mathrm{~h}$ & -0.564 & 0.28947 \\
$60^{\circ} \mathrm{C}-12 \mathrm{~h}$ & -0.683 & 0.40345 \\
$60^{\circ} \mathrm{C}-18 \mathrm{~h}$ & -0.519 & 0.07524 \\
$60^{\circ} \mathrm{C}-24 \mathrm{~h}$ & -0.254 & 0.05214 \\
$80^{\circ} \mathrm{C}-12 \mathrm{~h}$ & -0.623 & 0.03121 \\
$80^{\circ} \mathrm{C}-18 \mathrm{~h}$ & -0.243 & 0.00156 \\
$80^{\circ} \mathrm{C}-24 \mathrm{~h}$ & +0.016 & 0.00024 \\
$100^{\circ} \mathrm{C}-12 \mathrm{~h}$ & -0.099 & 0.03903 \\
$100{ }^{\circ} \mathrm{C}-18 \mathrm{~h}$ & +0.241 & 0.00001 \\
$100{ }^{\circ} \mathrm{C}-24 \mathrm{~h}$ & -0.122 & 0.00263 \\
\hline
\end{tabular}

In order to further understand the corrosion resistance ability of $\mathrm{MgAl} \mathrm{LDH}$, EIS analysis was performed. Figures 7 and 8 show the impedance modulus and phase plots, respectively. At low 
frequency (about $0.01 \mathrm{~Hz}$ ), higher impedance modulus values $\left(|\mathrm{Z}|_{0.01}\right)$ are a rough estimation of the corrosion resistance properties [42]: It can be seen that the samples $100{ }^{\circ} \mathrm{C}-24 \mathrm{~h}$ and $100{ }^{\circ} \mathrm{C}-18 \mathrm{~h}$ exhibit the highest value of $|Z|_{0.01}$ among the investigated samples. Furthermore, it is clear that $|Z|$ values follow a general tendency of corrosion resistance, higher temperature, and crystallization time and exhibit greater propensity of corrosion resistance, according to the higher thickness of the LDH layers. These results are consistent with the results obtained from the potentiodynamic curves. The specimens fabricated at $100{ }^{\circ} \mathrm{C}-24 \mathrm{~h}$ showed comparatively a lower corrosion resistance than $100{ }^{\circ} \mathrm{C}-18 \mathrm{~h}$, which may be due to their greater film thickness which causes more defects in the coating itself and/or pores at the interface with the substrate. The impedance results suggest that the high temperature and aging time lead to an increase in corrosion resistance, which is probably due to increased crystallization of the layered double hydroxide and to a thickening of the layer as well. When the temperature conditions and aging time are moderate, the enhancement in terms of corrosion resistance is less pronounced. In addition, the $|Z|$ values of the MgAl LDH film developed at different reaction conditions follow a general tendency: the higher the hydrothermal reaction temperature, the higher is the corresponding $|Z|$ value obtained. The thickness of the film also plays a vital role in corrosion protection, and $|Z|$ values vary with the increment in film thickness. The sample $\left(100{ }^{\circ} \mathrm{C}-18 \mathrm{~h}\right)$ showed around $33 \mu \mathrm{m}$ film thickness and also the highest corrosion resistance among all the processed samples.

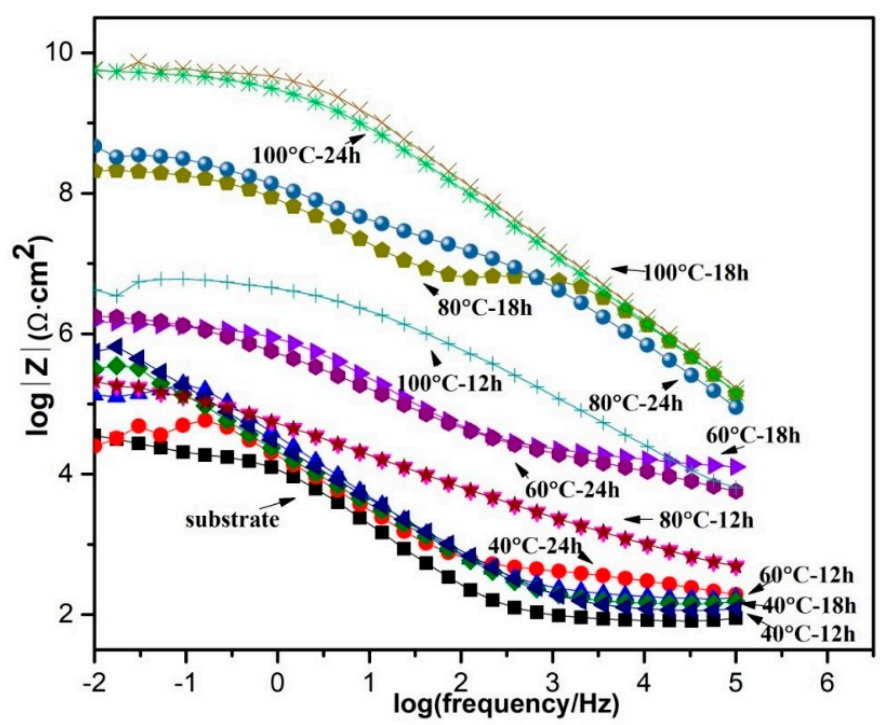

Figure 7. EIS spectra (Bode plots of $\log (|\mathrm{Z}|$ ) vs. $\log$ (frequency) ) of bare AA6082 alloy and AA6082 alloy coated with $\mathrm{LDH}$ film at various reaction temperatures and crystallization times in $0.1 \mathrm{M} \mathrm{NaCl}$ solution.
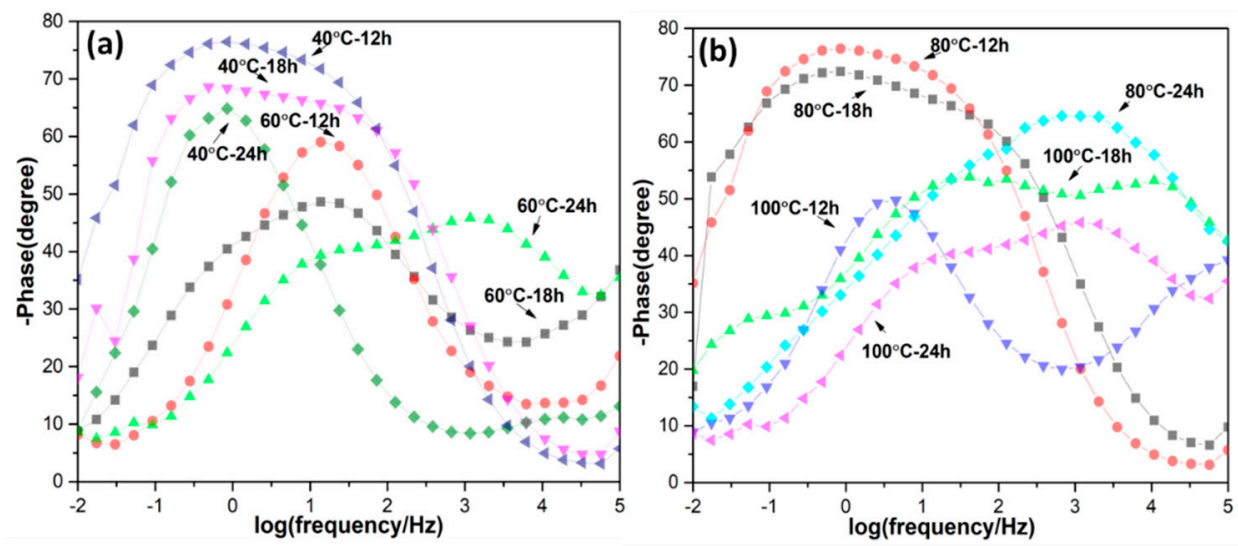

Figure 8. EIS spectra (Phase angle vs. $\log$ (frequency)) of bare AA6082 alloy and AA6082 alloy coated with $\mathrm{LDH}$ film at various reaction temperatures and crystallization times in $0.1 \mathrm{M} \mathrm{NaCl}$ solution. 
Figure 9 shows the evolution with an immersion time of the impedance modulus of the most representative samples among those investigated (data collected after 1, 3 and 7 days of immersion are reported). All the samples show a quite relevant decay of the protection properties during the 7 days of continuous immersion in the electrolyte. Regardless of the synthesis conditions, after one week of immersion, the low-frequency impedance is in the $10^{5}-10^{6} \Omega \mathrm{cm}^{2}$ range for all the investigated samples. This value is in any case remarkably higher than the $|Z|_{0.01}$ value of the bare substrate at the beginning of the immersion in the electrolyte $\left(|Z|_{0.01} \approx 10^{4} \Omega \mathrm{cm}^{2}\right)$. The decrease in impedance observed for the investigated coatings is likely to rely on the presence of porosity and defect in the coating and at the metal/LDH layer interface. According to optical microscope observations of the $\mathrm{LDH}$ layer and $\mathrm{LDH} /$ metal interface, thicker coatings (i.e., with synthesis conditions which promote higher LDH growth rate) are more defective and porous. This would explain the evolution of the impedance spectra with time: at the beginning, the LDH layers act as a barrier against electrolyte permeation; as time elapses, the solution moves through the defects and pores thus reaching the metal/coating interface. The latter process promotes a decrease in impedance over all the frequency range since coating resistance is reduced and the Faradic process is promoted.
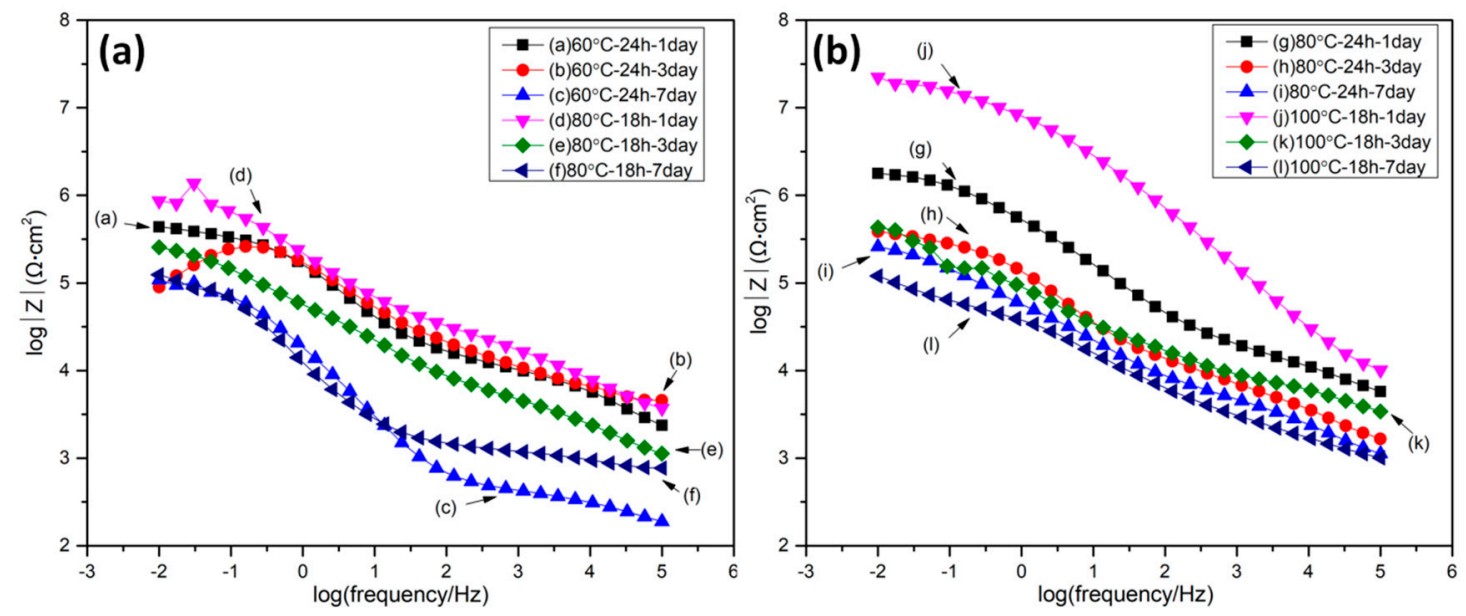

Figure 9. Bode plots of AA6082 samples, coated with $\mathrm{MgAl}-\mathrm{NO}_{3} \mathrm{LDH}$ thin film after immersion in $0.1 \mathrm{M} \mathrm{NaCl}$ : (a) $60{ }^{\circ} \mathrm{C}-24 \mathrm{~h}$ and $80^{\circ} \mathrm{C}-18 \mathrm{~h}$ sample from 1 to 7 days immersion; (b) $80{ }^{\circ} \mathrm{C}-24 \mathrm{~h}$ and $100{ }^{\circ} \mathrm{C}-18 \mathrm{~h} 1$ to 7 days immersion time.

The EIS spectra reported in Figure 9 were fitted in order to get some insight into the effect of the different parameters on the corrosion protection properties of the investigated coatings. According to Figure 8 , all the samples show two relaxation processes, which are located in the middle-high or middle-low frequency range. Notice that the thickness, as well as the defectiveness, of the coatings strongly affect the electrochemical response of the diverse samples. For this reason, it is not surprising to observe dispersion of the relaxation processes in the investigated frequency range. According to the literature $[43,44]$, the EIS response of the LDH covered samples can be analyzed employing a $R_{\mathrm{s}}\left(\mathrm{CPE}_{\mathrm{LDH}}\left(R_{\mathrm{LDH}}\left(\mathrm{CPE}_{\mathrm{dl}} R_{\mathrm{ct}}\right)\right)\right)$ electrical equivalent circuit. In this circuit, $R_{\mathrm{s}}$ stands for the resistance of the electrolyte. The relaxation process at the higher frequencies is fitted employing a resistance, $R_{\mathrm{LDH}}$, which indicates the pore resistance of the LDH layer and a constant phase element, $\mathrm{CPE}_{\mathrm{LDH}}$, which represents the dielectric properties of the layered double hydroxide coatings. The relaxation process at the lower frequencies is fitted employing a resistance, $R_{\mathrm{ct}}$, which is related to the superimposition of the contribution of the charge-transfer process and of the aluminum oxide and a constant phase element, $\mathrm{CPE}_{\mathrm{dl}}$, which represents the double layer capacitance contribution, overlapped to that of the dielectric properties of the aluminum oxide. According to the mathematical representation of a CPE, (i.e. $Z_{\mathrm{CPE}}=1 /\left(Q(\omega j)^{\alpha}\right)$ the parameters $Q$ and $\alpha$ were employed to describe the dielectric response of the electrodes. Table 4 shows the fitting results for the investigated samples. Notice that the parameters 
$\alpha_{\mathrm{LDH}}$ and $\alpha_{\mathrm{dl}}$ are almost always far from unity. For this reason, it is not possible to attribute any precise physical meaning to the pre-exponential factors $Q_{\mathrm{LDH}}$ and $Q_{\mathrm{dl}}$. As far as the $R_{\mathrm{LDH}}$ and $R_{\mathrm{ct}}$ parameters are concerned, one can observe a certain scattering during immersion time for the samples $60{ }^{\circ} \mathrm{C}-24 \mathrm{~h}$ and $80^{\circ} \mathrm{C}-18 \mathrm{~h}$, probably due to the porosity of the coatings and to the consequent localization of the corrosion attack promoted by chlorides. On the other hand, the samples $80^{\circ} \mathrm{C}-24 \mathrm{~h}$ and $100{ }^{\circ} \mathrm{C}-18 \mathrm{~h}$ show a smoother decrease in the corrosion protection properties (described by $R_{\mathrm{LDH}}$ and $R_{\mathrm{ct}}$ ) which indicates that the coatings are more compact (as suggested by the relatively high values of $R_{\mathrm{LDH}}$ ) and protective (as suggested by the relatively high values of $R_{\mathrm{ct}}$ ).

Table 4. Evolution with time of the fitting parameters $R_{\mathrm{LDH}}, Q_{\mathrm{LDH}}, \alpha_{\mathrm{LDH}}, R_{\mathrm{ct}}, Q_{\mathrm{dl}}$, and $\alpha_{\mathrm{dl}}$.

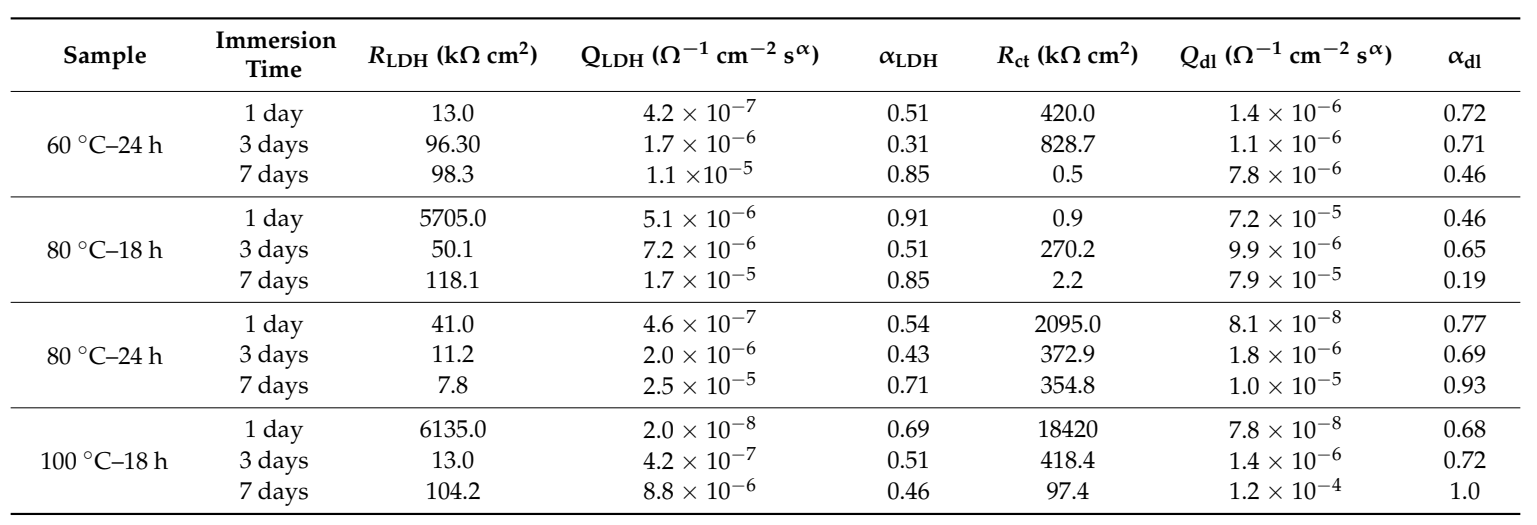

To better understand as to what extent the investigated LDH layers provide corrosion protection, the numerical values of $R_{\mathrm{LDH}}$ and $R_{\mathrm{ct}}$ obtained by fitting the experimental curves were compared with data from the literature. In Table 5, a comparison of the fitting parameters $R_{\mathrm{LDH}}$ and $R_{\mathrm{ct}}$ after about 1 day (or less) of immersion in a sodium chloride electrolyte is reported. The value of $R_{\mathrm{LDH}}$ for the coatings developed in this study is remarkably higher compared to the data reported in the literature. However, one should consider that: (1) in this study the crystallization treatment was prolonged in order to obtain relatively thick coatings, while in the literature very often only a thin conversion layer of LDHs was investigated; (2) the electrolyte employed in this study is more dilute than $3.5 \mathrm{wt} \% \mathrm{NaCl}$ $(0.1 \mathrm{M} \approx 0.58 \mathrm{wt} \%)$ : for this reason, higher resistance values are expected. Also the parameter $R_{\mathrm{ct}}$ for the samples investigated in this study is one of the highest compared to other works reported in the literature (except the LDH reported in [43], which contains vanadates based on corrosion inhibitors). However, also in this case it has to be considered that the electrolyte employed is more dilute compared to the $\mathrm{NaCl}$ concentration employed in the studies reported in [44-46].

Table 5. Comparison with literature data referring to LDH conversion layers/coatings on aluminum alloys (n.p.: not provided).

\begin{tabular}{cccccc}
\hline $\mathbf{L D H}$ & $\mathbf{N a C l}$ Concen. & Time & $\boldsymbol{R}_{\mathbf{L D H}} \mathbf{( \mathbf { k } \boldsymbol { \Omega } \mathbf { ~ c m } ^ { \mathbf { 2 } } )}$ & $\boldsymbol{R}_{\mathbf{c t}}\left(\mathbf{k} \boldsymbol{\Omega} \mathbf{c m}^{\mathbf{2}}\right)$ & Ref. \\
\hline $\mathrm{Li} / \mathrm{Al}$ & $3.5 \mathrm{wt} \%$ & $0 \mathrm{~h}$ & 2.2 & $6.49 \times 10^{3}$ & {$[43]$} \\
$\mathrm{Mg} / \mathrm{Al}$ & $3.5 \mathrm{wt} \%$ & 1 day & n.p. & 5.88 & {$[44]$} \\
$\mathrm{Li} / \mathrm{Al}$ & $3.5 \mathrm{wt} \%$ & 1 day & 0.8 & $0.18 \times 10^{3}$ & {$[45]$} \\
$\mathrm{Zn} / \mathrm{Al}\left(+\mathrm{VO}_{x}\right)$ & $0.05 \mathrm{M}$ & 1 day & 18.2 & $7.96 \times 10^{8}$ & {$[46]$} \\
$\mathrm{Mg} / \mathrm{Al} 80^{\circ} \mathrm{C}-24 \mathrm{~h}$ & $0.1 \mathrm{M}$ & 1 day & 41.0 & $2.09 \times 10^{3}$ & This work \\
$\mathrm{Mg} / \mathrm{Al} 100^{\circ} \mathrm{C}-18 \mathrm{~h}$ & & & 6135.0 & $18.4 \times 10^{3}$ & \\
\hline
\end{tabular}

The EIS results seem also to be in accordance with the visual observation of the immersed samples as shown in Figure 10: optical microscope photos were taken after the 7 days of immersion in $0.1 \mathrm{M}$ $\mathrm{NaCl}$ solution. The bare aluminum sample was badly corroded after the immersion and was covered with a thick layer of corrosion products. Notice that cracks and blister are observed on the LDH layers, in accordance with the remarkable decrease in $R_{\mathrm{LDH}}$ and $R_{\mathrm{ct}}$. 


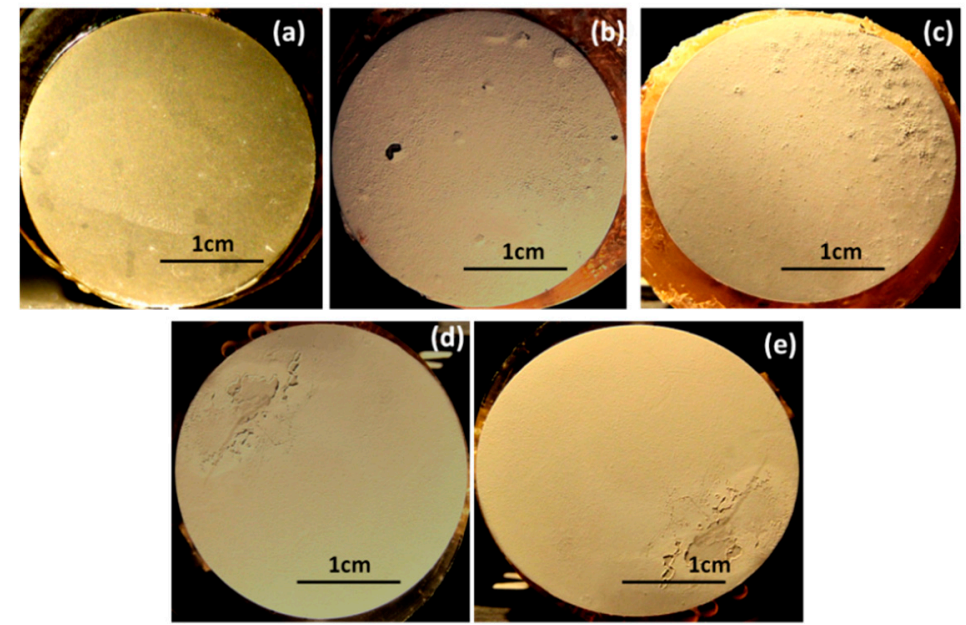

Figure 10. The specimens after 7 days of immersion in a solution of $0.1 \mathrm{M} \mathrm{NaCl}$ : (a) bare aluminum surface; (b) coated sample at $60{ }^{\circ} \mathrm{C}-24 \mathrm{~h}$; (c) $80^{\circ} \mathrm{C}-18 \mathrm{~h}$; (d) $80^{\circ} \mathrm{C}-24 \mathrm{~h}$; and (e) $100{ }^{\circ} \mathrm{C}-18 \mathrm{~h}$.

The surface morphologies of the MgAl-LDH after 7 days immersion in $0.1 \mathrm{M} \mathrm{NaCl}$ solution are shown in Figure 11. It can be seen that no serious collapse of platelet structure is observed after 7 days immersion and most of the structure remained almost intact and was shown to be similar to the as-prepared original structure (Figure 11a,b). However, due to the longtime contact, dissolution of some platelets of MgAl-LDH structure was observed at some points Strong $\mathrm{Cl}^{-}$signals in EDS analysis (inset of Figure 11b) were observed after contact with chloride solution, so we can say that the MgAl-LDH film exhibited anion exchange capability by absorbing $\mathrm{Cl}^{-}$while the XRD analysis also showed that the interlayer of the MgAl-LDH was able to retain $\mathrm{Cl}^{-}$inside the structure. The $\mathrm{LDH}$ film anion-exchange behavior on the aluminum alloy in the chloride solution can be generally expressed as follows [27]:

$$
\mathrm{LDH}-\mathrm{NO}_{3}{ }^{-}+2 \mathrm{Cl}^{-} \rightarrow \mathrm{LDH}-2 \mathrm{Cl}^{-}+\mathrm{NO}_{3}{ }^{-}
$$

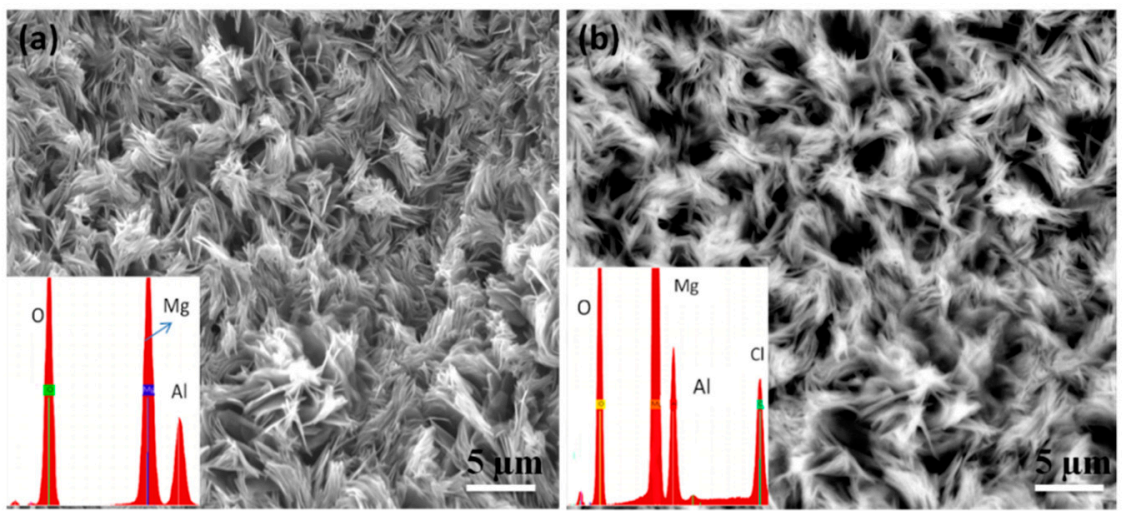

Figure 11. SEM images of (a) original $\mathrm{MgAl} \mathrm{LDH}$ coating, $60{ }^{\circ} \mathrm{C}-24 \mathrm{~h}$ sample and (b) an immersed sample soaked in $0.1 \mathrm{M} \mathrm{NaCl}$ solution for 7 days (Insets are the corresponding EDS spectra).

\section{Conclusions}

The finding demonstrated that the reaction temperature and crystallization times have an influential effect on the growth mechanism of layered double hydroxide which ultimately has a strong impact on its corrosion resistance behavior. Well-grown uniformed structures were obtained at 80 and $100{ }^{\circ} \mathrm{C}$ with crystallization times of 18 and $24 \mathrm{~h}$ while the thickness of the obtained films lay in the range of 24-74 $\mu \mathrm{m}$, which also imparted a significant influence on the corrosion resistance properties. The results from polarization curves confirmed that $\mathrm{MgAl} \mathrm{LDH}$ stands as an improved 
corrosion protection thin film, which demonstrates significantly high impedance and low corrosion current density as compared to the substrate. The thicker coatings ( $>30 \mu \mathrm{m}$, obtained on treating the substrate at $100{ }^{\circ} \mathrm{C}$ for 18 and $24 \mathrm{~h}$ ) showed a remarkable decrease of the corrosion current (3-4 orders of magnitude) and a remarkable increase in low-frequency impedance $\left(|Z|_{0.01}\right)$ compared to the bare substrate. However, the long-term durability of the investigated coating is still an issue as after about one week of immersion in the $0.1 \mathrm{M} \mathrm{NaCl}$ solution, the impedance in the low-frequency range showed a decrease of a few orders of magnitude. Compared to the bare substrate the investigated coatings were revealed to be in any case quite protective compared to the bare AA6082 substrate.

Author Contributions: Conceptualization, M.F.; Data curation, M.A.I.; Formal analysis, M.A.I.; Funding acquisition, M.F.; Investigation, M.A.I.; Methodology, M.F. and M.A.I.; Supervision, M.F.; Project administration, M.F.; visualization, M.A.I., Writing—original draft, M.A.I.; Writing—review \& editing, M.F.

Funding: This research received no external funding.

Conflicts of Interest: The authors declare no conflict of interest.

\section{References}

1. Davis, J.R. Corrosion of Aluminium and Aluminium Alloys; ASM International: Novelty, OH, USA, 1999.

2. Revie, R.W. Corrosion and Corrosion Control: An Introduction to Corrosion Science and Engineering, 4th ed.; John Wiley \& Sons: New York, NY, USA, 2008.

3. Xhanari, K.; Finšgar, M. Organic corrosion inhibitors for aluminum and its alloys in chloride and alkaline solutions: A review. Arab. J. Chem. 2016, in press. [CrossRef]

4. Kumar, N.; Rao, P.N.; Jayaganthan, R.; Brokmeier, H.G. Effect of cryorolling and annealing on recovery, recrystallisation, grain growth and their influence on mechanical and corrosion behaviour of $6082 \mathrm{Al}$ alloy. Mater. Chem. Phys. 2015, 165, 177-187. [CrossRef]

5. Liang, W.J.; Rometsch, P.A.; Cao, L.F.; Birbilis, N. General aspects related to the corrosion of 6xxx series aluminium alloys: Exploring the influence of $\mathrm{Mg} / \mathrm{Si}$ ratio and $\mathrm{Cu}$. Corros. Sci. 2013, 76, 119-128. [CrossRef]

6. Larsen, M.H.; Walmsley, J.C.; Lunder, O.; Mathiesen, R.H.; Nisancioglu, K. Intergranular corrosion of copper-containing AA6xxx AlMgSi aluminum alloys. J. Electrochem. Soc. 2008, 155, C550-C556. [CrossRef]

7. Zubillaga, O.; Cano, F.J.; Azkarate, I.; Molchan, I.S.; Thompson, G.E.; Skeldon, P. Anodic films containing polyaniline and nanoparticles for corrosion protection of AA2024T3 aluminium alloy. Surf. Coat. Technol. 2009, 203, 1494-1501. [CrossRef]

8. Boisier, G.; Lamure, A.; Pébère, N.; Portail, N.; Villatte, M. Corrosion protection of AA2024 sealed anodic layers using the hydrophobic properties of carboxylic acids. Surf. Coat. Technol. 2009, 203, 3420-3426. [CrossRef]

9. Johansen, H.D.; Brett, C.M.; Motheo, A.J. Corrosion protection of aluminium alloy by cerium conversion and conducting polymer duplex coatings. Corros. Sci. 2012, 63, 342-350. [CrossRef]

10. Shi, H.; Han, E.H.; Liu, F.; Kallip, S. Protection of 2024-T3 aluminium alloy by corrosion resistant phytic acid conversion coating. Appl. Surf. Sci. 2013, 280, 325-331. [CrossRef]

11. Schäfer, H.; Stock, H.R. Improving the corrosion protection of aluminium alloys using reactive magnetron sputtering. Corros. Sci. 2005, 47, 953-964. [CrossRef]

12. Diesselberg, M.; Stock, H.R.; Mayr, P. Corrosion protection of magnetron sputtered TiN coatings deposited on high strength aluminium alloys. Surf. Coat. Technol. 2004, 177-178, 399-403. [CrossRef]

13. Arenas, M.A.; Conde, A.; de Damborenea, J.J. Effect of acid traces on hydrothermal sealing of anodising layers on 2024 aluminium alloy. Electrochim. Acta 2010, 55, 8704-8708. [CrossRef]

14. Venugopal, A.; Panda, R.; Manwatkar, S.; Sreekumar, K.; Krishna, L.R.; Sundararajan, G. Effect of micro arc oxidation treatment on localized corrosion behaviour of AA7075 aluminum alloy in $3.5 \% \mathrm{NaCl}$ solution. Trans. Nonferrous Met. Soc. China 2012, 22, 700-710. [CrossRef]

15. Dalmoro, V.; dos Santos, J.H.; Armelin, E.; Alemán, C.; Azambuja, D.S. A synergistic combination of tetraethylorthosilicate and multiphosphonic acid offers excellent corrosion protection to AA1100 aluminum alloy. Appl. Surf. Sci. 2013, 273, 758-768. [CrossRef]

16. Voevodin, N.N.; Kurdziel, J.W.; Mantz, R. Corrosion protection for aerospace aluminum alloys by modified selfassembled nanophase particle (MSNAP) sol-gel. Surf. Coat. Technol. 2006, 201, 1080-1084. [CrossRef] 
17. Qu, J.E.; Geng, C.H.E.N.; Wang, H.R.; Nie, D.J. Effect of water content on corrosion inhibition behavior of self-assembled TDPA on aluminum alloy surface. Trans. Nonferrous Met. Soc. China 2013, 23, 3137-3144. [CrossRef]

18. Zou, K.; Wang, X.; Liu, W.; Zhao, Y. Preparation and characterization of $\mathrm{Ce}-$ silane $-\mathrm{ZrO}_{2}$ composite coatings on 1060 aluminum. Trans. Nonferrous Met. Soc. China 2014, 24, 1474-1480.

19. Lutz, A.; van den Berg, O.; Van Damme, J.; Verheyen, K.; Bauters, E.; De Graeve, I.; Du Prez, F.; Terryn, H. A shape-recovery polymer coating for the corrosion protection of metallic surfaces. ACS Appl. Mater. Interfaces 2014, 7, 175-183. [CrossRef]

20. Ates, M. A review on conducting polymer coatings for corrosion protection. J. Adhes. Sci. Technol. 2016, 30, 1510-1536. [CrossRef]

21. Leroux, F.; Taviot-Guého, C. Fine tuning between organic and inorganic host structure: New trends in layered double hydroxide hybrid assemblies. J. Mater. Chem. 2005, 15, 3628-3642. [CrossRef]

22. Evans, D.G.; Duan, X. Preparation of layered double hydroxides and their applications as additives in polymers, as precursors to magnetic materials and in biology and medicine. Chem. Commun. 2006, 5, 485-496. [CrossRef]

23. Williams, G.R.; O'Hare, D. Towards understanding, control and application of layered double hydroxide chemistry. J. Mater. Chem. 2006, 16, 3065-3074. [CrossRef]

24. Lei, X.D.; Yang, L.; Zhang, F.Z.; Evans, D.G.; Duan, X. Synthesis of oriented layered double hydroxide thin films on sulfonated polystyrene substrates. Chem. Lett. 2005, 34, 1610-1611. [CrossRef]

25. Chen, H.; Zhang, F.; Fu, S.; Duan, X. In situ microstructure control of oriented layered double hydroxide monolayer films with curved hexagonal crystals as superhydrophobic materials. Adv. Mater. 2006, 18, 3089-3093. [CrossRef]

26. Wang, L.; Li, C.; Liu, M.; Evans, D.G.; Duan, X. Large continuous, transparent and oriented self-supporting films of layered double hydroxides with tunable chemical composition. Chem. Commun. 2007, 2, 123-125. [CrossRef] [PubMed]

27. Zhang, F.; Zhang, C.; Song, L.; Zeng, R.; Liu, Z.; Cui, H. Corrosion of in-situ grown MgAl-LDH coating on aluminum alloy. Trans. Nonferrous Met. Soc. China 2015, 25, 3498-3504. [CrossRef]

28. Lin, J.-K.; Jeng, K.-L.; Uan, J.-Y. Crystallization of a chemical conversion layer that forms on AZ91D magnesium alloy in carbonic acid. Corros. Sci. 2011, 53, 3832-3839. [CrossRef]

29. Wang, X.; Li, L.; Xie, Z.-H.; Yu, G. Duplex coating combining layered double hydroxide and 8-quinolinol layers on $\mathrm{Mg}$ alloy for corrosion protection. Electrochim. Acta 2018, 283, 1845-1857. [CrossRef]

30. Wang, L.; Zhang, K.; He, H.; Sun, W.; Zong, Q.; Liu, G. Enhanced corrosion resistance of MgAl hydrotalcite conversion coating on aluminum by chemical conversion treatment. Surf. Coat. Technol. 2013, 235, 484-488. [CrossRef]

31. Liu, Z.; Ma, R.; Osada, M.; Iyi, N.; Ebina, Y.; Takada, K.; Sasaki, T. Synthesis, anion exchange, and delamination of $\mathrm{Co}-\mathrm{Al}$ layered double hydroxide: Assembly of the exfoliated nanosheet/polyanion composite films and magneto-optical studies. J. Am. Chem. Soc. 2006, 128, 4872-4880. [CrossRef]

32. Okamoto, K.; Iyi, N.; Sasaki, T. Factors affecting the crystal size of the MgAl-LDH (layered double hydroxide) prepared by using ammonia-releasing reagents. Appl. Clay Sci. 2007, 37, 23-31. [CrossRef]

33. Wu, L.; Zheng, Z.; Pan, F.; Tang, A.; Zhang, G.; Liu, L. Influence of Reaction Temperature on the Controlled Growth of Mg-Al LDH Film. Int. J. Electrochem. Sci. 2017, 12, 6352-6364. [CrossRef]

34. Cullity, B.D. Elements of X-ray Diffraction; Pearson Education: London, UK, 2014.

35. Iqbal, M.A.; Fedel, M. The effect of the surface morphologies on the corrosion resistance of in situ growth MgAl-LDH based conversion film on AA6082. Surf. Coat. Technol. 2018, 352, 166-174. [CrossRef]

36. Aisawa, S.; Hirahara, H.; Uchiyama, H.; Takahashi, S.; Narita, E. Synthesis and thermal decomposition of Mn-Al layered double hydroxides. J. Solid State Chem. 2002, 167, 152-159. [CrossRef]

37. Wu, Q.; Olafsen, A.; Vistad, Ø.B.; Roots, J.; Norby, P. Delamination and restacking of a layered double hydroxide with nitrate as counter anion. J. Mater. Chem. 2005, 15, 4695-4700. [CrossRef]

38. Kloprogge, J.T.; Frost, R.L. Fourier transform infrared and Raman spectroscopic study of the local structure of Mg-, Ni-, and Co-hydrotalcites. J. Solid State Chem. 1999, 146, 506-515. [CrossRef]

39. Ni, Z.M.; Xia, S.J.; Fang, C.P.; Wang, L.G.; Hu, J. Synthesis, characterization and thermal property of $\mathrm{Cu} / \mathrm{Co} / \mathrm{Mg} / \mathrm{Al}$ hydrotalcite like compounds. Rare Met. Mater. Eng. 2008, 37, 634-637. 
40. Beving, D.E.; McDonnell, A.M.; Yang, W.; Yan, Y. Corrosion resistant high-silica-zeolite MFI coating one general solution formulation for aluminum alloy AA-2024-T3, AA-5052-H32, AA-6061-T4, and AA-7075-T6. J. Electrochem. Soc. 2006, 153, B325-B329. [CrossRef]

41. Tedim, J.; Kuznetsova, A.; Salak, A.N.; Montemor, F.; Snihirova, D.; Pilz, M.; Zheludkevich, M.L.; Ferreira, M.G.S. Zn-Al layered double hydroxides as chloride nanotraps in active protective coatings. Corros. Sci. 2012, 55, 1-4. [CrossRef]

42. Zhang, F.; Liu, Z.G.; Zeng, R.C.; Li, S.Q.; Cui, H.Z.; Song, L.; Han, E.H. Corrosion resistance of Mg-Al-LDH coating on magnesium alloy AZ31. Surf. Coat. Technol. 2014, 258, 1152-1158. [CrossRef]

43. Zhang, C.; Luo, X.; Pan, X.; Liao, L.; Wu, X.; Liu, Y. Self-healing Li-Al layered double hydroxide conversion coating modified with aspartic acid for 6N01 Al alloy. Appl. Surf. Sci. 2017, 394, 275-281. [CrossRef]

44. Wang, F.; Guo, Z. In situ growth of durable superhydrophobic Mg-Al layered double hydroxides nanoplatelets on aluminum alloys for corrosion resistance. J. Alloy. Compd. 2018, 767, 382-391. [CrossRef]

45. Lin, K.; Luo, X.; Pan, X.; Zhang, C.; Liu, Y. Enhanced corrosion resistance of LiAl-layered double hydroxide (LDH) coating modified with a Schiff base salt on aluminum alloy by one step in situ synthesis at low temperature. Appl. Surf. Sci. 2019, 463, 1085-1096. [CrossRef]

46. Tedim, J.; Zheludkevich, M.L.; Bastos, A.C.; Salak, A.N.; Lisenkov, A.D.; Ferreira, M.G.S. Influence of preparation conditions of layered double hydroxide conversion films on corrosion protection. Electrochim. Acta 2014, 117, 164-171. [CrossRef]

(C) 2019 by the authors. Licensee MDPI, Basel, Switzerland. This article is an open access article distributed under the terms and conditions of the Creative Commons Attribution (CC BY) license (http://creativecommons.org/licenses/by/4.0/). 